CIRJE-F-470

\title{
Dark Matter: Some Reflections on the Current Account Debate
}

\author{
Tanweer Akram \\ ING Investment Management \\ Haider A. Khan \\ University of Denver
}

February 2007

CIRJE Discussion Papers can be downloaded without charge from:

http://www.e.u-tokyo.ac.jp/cirje/research/03research02dp.html

Discussion Papers are a series of manuscripts in their draft form. They are not intended for circulation or distribution except as indicated by the author. For that reason Discussion Papers may not be reproduced or distributed without the written consent of the author. 
Working Paper

\title{
DARK MATTER: SOME REFLECTIONS ON THE CURRENT ACCOUNT DEBATE
}

\author{
Tanweer Akram* \\ and \\ Haider A. Khan ${ }^{+}$ \\ Dated: February 6, 2007
}

\footnotetext{
* Address: ING Investment Management, 5780 Powers Ferry Rd NW, Suite 300, Atlanta, GA 30327, U.S.A. Email: tanweer_akram@hotmail.com
}

+ Corresponding author. Address: Graduate School of International Studies, University of Denver, Denver, CO 80208, U.S.A. Email: hkhan@du.edu.

The standard disclaimer holds. 


\section{DARK MATTER: SOME REFLECTIONS ON THE CURRENT ACCOUNT DEBATE}

\footnotetext{
ABSTRACT

The United States has a large and persistent current account deficit. Yet, U.S.'s income receipts from the rest of the world have exceeded its income payments to the rest of the world for many years. This appears to be paradoxical because for a country with a negative net foreign assets position, such as the U.S., international income payments to the rest of the world are likely to exceed its international income receipts. Hausmann and Sturzenegger (2005) offer an explanation of this apparent paradox. They argue that U.S. current account statistics do not properly measure U.S.'s net foreign assets position and that its actual net foreign assets position is measurably better than the officially estimated position primarily due to the existence of intangible corporate capital invested overseas. In their view the debate about the sustainability of the U.S. current account deficit and the negative net foreign assets position is moot because these deficits and debts are either non-existent or fairly small. This paper critically evaluates Hausmann et al's claims and examines the implications of their hypothesis. It offers, within an analytical framework, alternative explanations that are more consistent with the stylized facts. (JEL F02, F31, F23, F32, F34, F41, F42)
}

Key words: International finance, current account, financial and capital account, balance of payments, U.S. current account deficit, current account sustainability, dark matter, intangible capital 


\section{DARK MATTER: SOME REFLECTIONS ON THE CURRENT ACCOUNT DEBATE}

The United States has a large current account deficit that has widened measurably over the past 15 years. Recently, as a share of U.S. Gross Domestic Product, the current account deficit widened to $6.4 \%$ in 2005 , compared to $5.7 \%$ in 2004 . A large and widening current account deficit implies that the U.S. is becoming more indebted to foreigners.

A widening and persistent current account deficit results in the reduction of a country's net foreign assets. A country with a negative net foreign assets position would ordinarily be running a deficit on its balance of income because it has to service its foreign liabilities. Other things held constant, for a country with a negative net foreign assets position, such as the U.S., international income payments to the rest of the world are likely to exceed its international income receipts from the rest of the world provided the rates of return on its liabilities and its assets are not much different. Yet, U.S. income receipts from the rest of the world have exceeded its income payments to the rest of the world for many years. This appears to be paradoxical.

Two leading academics, Professors Ricardo Hausmann and Federico Sturzenegger, have recently offered an explanation of this apparent paradox. ${ }^{1}$ They argue that U.S. current account statistics do not properly measure U.S. net foreign assets. They conjecture that U.S. net foreign assets, if calibrated on the basis of capitalizing income receipts and income payments, exceeded officially estimated U.S. net foreign assets. They call these extra assets "dark matter." They claim that the U.S. has not run current account deficits and that global imbalances are much smaller than that reported in official statistics. They cite the continuance of the U.S.'s net income receipts for many years to dispute the validity of the current account data. They claim that the official current account deficit is an artifact of the deficiency of the data, which do not adequately capture U.S.'s exports of "dark matter" consisting of intangible capital.

\footnotetext{
${ }^{1}$ See Hausman and Sturzenegger, "U.S. and Global Imbalances: Can Dark Matter Prevent a Big Bang?" (November 2005) and "Global Imbalances or Bad Accounting? The Missing Dark Matter in the Wealth of Nations," CIP Working Paper No. 124, Center for International Development at Harvard University (May 2006).
} 
If Hausmann and Sturzenegger's (henceforth, H\&S) conjectures about the existence and the magnitude of "dark matter" are true, then the debate about global imbalances and the adjustment of U.S. current account deficit is largely moot. This is an important issue because if the U.S. current account is not as large as the official data indicate then the U.S. economy and, indeed, the world economy are much healthier than it is generally believed to be the case. It also implies that the downside risk to the global economy of an abrupt and large adjustment in current account imbalances, cross-border financial and capital flows, and exchange rates are much less than what many policymakers and analysts believe. If global imbalances are small, then the necessity of rebalancing is suspect and the amount of capital flow required to redress these longterm imbalances would be fairly negligible. Debates about the long-term sustainability of the U.S. current account deficit and the negative net foreign assets position becomes irrelevant if these deficits and debts are non-existent or fairly small as H\&S claim.

This paper critically evaluates $H \& S^{\prime}$ s provocative and controversial hypothesis. It examines the implications of their hypothesis for the U.S. current account deficit. It presents first the analytical framework within which H\&S examine the relevant issues. It then goes on to review the stylized facts about U.S. current account and provides an exposition of their hypothesis.

After critically evaluating their claims, it is argued that there are quite plausible and robust explanations for the U.S. to continue to have net income receipts on its balance of income at least for a while despite its current account deficit. It is argued here that $H \& S^{\prime}$ s claims are questionable and that the methodology they have used to arrive at their conjectures is affected by specious assumptions. It would, hence, be imprudent to pursue a policy of benign neglect of the U.S. current account deficit.

While rebalancing of global imbalances is a joint responsibility of the international community, including the U.S.'s major trading partners, U.S. policymakers should encourage higher private saving, particularly household saving, and also public saving in order to facilitate a gradual adjustment of the current account deficit, leading to an orderly correction of global imbalances.

\section{SECTION I: The Analytical Framework}

It is well known that the current account is related to the change in the net foreign assets position of a country. This can be expressed as: $C A=\triangle N F A$. We can, therefore, write using discrete time variables, $N F A_{t}=N F A_{t-1}+\Delta N F A_{t}=N F A_{t-1}+C A_{t}$.

But H\& S point out that the stock of foreign assets does not evolve strictly according to this rule but rather according to a stochastic formulation that can be written as: 


$$
N F A_{t}=N F A_{t-1}+\Delta N F A_{t}+\varepsilon_{t}=N F A_{t-1}+C A_{t}+\varepsilon_{t}
$$

In the long run it is expected that $\varepsilon=0$.

H\&S add:

This is the relationship that is in most analysts' minds, and explains why people worry about large negative external positions. In fact, this is the rationale that we followed in the introduction of this paper, only to find out that it led to a very large inconsistency. The problem comes from the fact that given the standard accounting rules the capital gains can be very substantial and persistent making the relationship between the current account and the change in net foreign assets quite weak.

Thus we propose a different set of accounting rules, a system that rescues the relationship between our definition of the current account and the change in net foreign assets by defining the first as the change in the latter. In short we will assume that $C A=\triangle N F A$ by definition (which is tantamount to making $\varepsilon \equiv 0$ ).

But to implement this definition we need to adopt a rule for valuing assets. We start by assuming that if an asset consistently pays more than another asset, then it is worth more, even if they both have the same historical cost or "book" or face value. Choosing to value the assets on the basis of their returns is just like valuing a company by calculating its earnings and multiplying by some price-earnings ratio, or valuing a property based on its rental value. As we know from the corporate finance literature for an individual company, the earnings of any given year may give an unreliable measure of its true earning potential, but if we average over an economy and look at trends over a couple of years, this simple methodology delivers reasonable results. Of course, this opens the question as to what exactly this price earning ratio should be and why the discount rate should be the same, even for assets with very large differences in risk characteristics, a point to which we will come back at length below. For the purpose of illustrating the implications let us use here an arbitrary $5 \%$ rate, which implies a price-earnings ratio of 20.

With this we can do some quick back of envelope estimations. Japan, for example, has net income from investments ( NII ) of 86 billion which delivers an estimate of net foreign assets of 1.7 trillion. The US net income on its financial portfolio is 36 billion dollars. This is a 5 percent return on an asset of 720 billion dollars. So we would say that the US is a net creditor for about 720 billion dollars or about 5 percent of its GDP.

With this definition for the value of assets, they go on to compute the current account as the change in the value of this net foreign assets position. That is,

$$
C A_{t}=\frac{N I I_{t}-N I I_{t-1}}{r}
$$

They then claim: 
This new version of the current account can be easily computed for any country. To return to our previous examples, for Japan, the cumulative official current account between 1980 and 2004 is 2.0 trillion dollars. The difference in the capitalized income flows (our estimation of the cumulative current account) amounts to 1.7 trillion. In the case of Australia the two numbers amount to a deficit of 357 billion and 352 respectively, and so on

\section{What About the "Dark Matter"?}

$H \& S$ ask the reader to imagine a country that reports a sequence of officially measured net foreign assets equal to $\left\{. . . N F A_{t}, N F A_{t-1}, N F A_{t+1}, \ldots\right\}$ which earn a rate of return $\tilde{r}_{t}$, in period $t$. Since assets may be measured with error they postulate an estimation error $\mu_{t}$. Thus, their measure of the current account can be written as:

$$
C A_{t}=\frac{\tilde{r}\left(N F A_{t}+\mu_{t}\right)}{r}-\frac{\tilde{r}_{t-1}\left(N F A_{t-1}+\mu_{t-1}\right)}{r}
$$

After some simplifications the above equation [2] can be rewritten as:

$$
C A_{t} \approx C A^{0}+\frac{\Delta \tilde{r}_{t}}{r} \frac{\left(N F A_{t}+\mu_{t}\right)}{r}+\left(\mu_{t}-\mu_{t-1}\right)
$$

which in turn implies that

$$
X^{D M}=C A-C A^{0}=\left(\mu_{t}-\mu_{t-1}\right)+\frac{\Delta \tilde{r}_{t}}{r} \frac{\left(N F A_{t}+\mu_{t}\right)}{r}
$$

where $X^{D M}$ is the amount of "dark matter."

They conclude that exports of "dark matter," $X^{D M}$ has two basic sources. The first term is the increase in the amount of assets that we know exist, since they generate revenue, but cannot be seen or properly measured. In fact it is this idea that motivates the name "dark matter," which is taken from a term used in physics to account for the fact that the world is more stable than you would think if it were held together only by the gravity emanating from visible matter. Equation [4] shows, however, that there is another component of "dark matter," arising from the fact that assets of a given country may earn more (or less) than the benchmark return.

It remains to clarify the meaning in an accounting sense of using a common interest rate. They consider an asset that is held abroad that earns a rate of return $r^{h}$, which is higher than their fixed and arbitrary benchmark rate of 5\%, and a liability earning $r^{l}$, which is lower than the benchmark rate. If $A$ and $L$ represent the market value of the assets and liabilities then based on their accounting assets and liability would be measured as follows: 


$$
A^{*}=\frac{r^{h} A}{r}>A=\frac{r^{h} A}{r}+\frac{\left(r-r^{h}\right)}{r} A
$$

This implies that $A^{*}=A+\frac{\left(r^{h}-r\right)}{r} A$

In other words they add to the value of the asset the second term, the capitalized value of the return differential of this investment. By capitalizing this they are in fact assuming that this return differential will persist. It may be recalled that in H\&S type accounting, the ability to obtain a higher return is an asset, the value of which is equivalent to an export of "dark matter."

Likewise, the value for liabilities $L^{*}$ can be written as:

$$
L^{*}=\frac{r^{l} L}{r}<L=\frac{r^{l} L}{r}+\frac{\left(r-r^{l}\right) L}{r}
$$

which implies that

$$
L^{*}=L-\frac{\left(r-r^{l}\right) L}{r}
$$

If the interest rate paid is lower than their benchmark, the second term shows a reduction in liabilities equal to the capitalized value of that interest differential. Thus, H\&S interpret the ability of the U.S. to pay lower rates is an asset (a negative liability), the value of which is measured in the second term in the previous equation. Therefore, this term would account for exports of "dark matter."

Having presented H\&S's theory we now turn to stylized facts.

\section{SECTION II: Stylized Facts}

The U.S.'s large and persistent current account deficit has become an issue of concern because it raises questions about the long-term sustainability of the current account deficit at its current levels and the increased indebtedness to foreigners. ${ }^{2}$ A

2 See Zandi (2005) for a detailed discussion of global imbalances, with a careful examination of the evolution and the causes of U.S trade deficits and saving-investment gap, and an analysis of adjustment under soft landing and hard landing scenarios and their implications. 
large and persistent deficit requires foreigners to be willing to continue to finance it by purchasing U.S.-dollar denominated assets, issued by the U.S. government and by other U.S. residents.

Since the early 1990s the current account deficit has ballooned. The nominal current account deficit in 1990 was less than $1.4 \%$ of nominal GDP, amounting to less than $\$ 80$ billion. But by 2005 , it grew to more than $6.4 \%$ of nominal GDP, amounting to $\$ 790$ billion (see Chart 1).

\section{$<$ INSERT CHART [1] HERE $>$}

The U.S. is the world's largest importer of capital as the large current account deficit requires the U.S. to absorb $65 \%$ of the global cross-border flow of capital (see Chart 2). Its capital requirement exceeds by far that of all other capital-importing countries of the world. Among the other notable countries that import capital are Spain, U.K., and Australia, countries which also run large current account deficits. But their voracity for foreign capital is moderate when compared to that of the U.S. Together the U.S., Spain, U.K. and Australia account for more than three-fourths of the global demand for capital.

\section{<INSERT CHART [2] HERE >}

In Asia, Japan and China are the major sources of cross-border capital (see Chart 3). Germany is also a leading exporter of capital. Saudi Arabia, Russia, the Nordic countries, and Switzerland are also important exporters of capital. The capital-exporting countries run surpluses on their current account. Countries that are either major exporters of manufactured goods, such as Japan, China, and Germany, or the key suppliers of commodities particularly net exporters of crude oil, such as Saudi Arabia, Russia, and United Arab Emirates, are the leading exporters of capital. Soaring prices of crude oil and other commodities have boosted the roles of oil-producing and other commodity-producing countries as sources of cross-border capital flows.

\section{<INSERT CHART [3] HERE >}

The current account consists of three components. These components are the trade balance, the balance on income, and net unilateral transfers. The trade balance calibrates the difference between the exports and the imports of goods and services between the U.S. and the rest of the world. The trade deficit measures the country's shortfall of exports of goods and services over its import of goods and services. The U.S.'s trade deficit is the key driver of its current account deficit (see Chart 4). The balance of income measures the difference between income receipts on U.S.-owned assets abroad, including direct investments, other private assets, U.S. government assets, and compensation of U.S. employees overseas and income payments on foreign-owned U.S. assets, including direct investments, other private assets, U.S. government payments, and compensation of foreign employees. The remaining item in the current account is net unilateral transfers, which is the difference between the unilateral public and private 
transfers received from abroad by U.S. residents and the unilateral transfers sent abroad by U.S. residents and the U.S. government. U.S. is a net provider of public and private transfers to the rest of the world and thus runs a deficit on the net unilateral transfers.

\section{$<$ INSERT CHART [4] HERE $>$}

Whereas the U.S. runs a deficit on its trade balance and on its net unilateral transfers, it runs a small surplus on its balance of income (see Chart 5). While the trade balance and net unilateral transfers have been in the red since the 1990s, the balance of income has held steady for many years.

\section{$<$ INSERT CHART [5] HERE >}

The surplus on the balance of income is somewhat counterintuitive. If a country has a current account deficit then it adversely affects its net foreign assets position. With the U.S. running large trade and current account deficits consistently since the 1990s, the U.S. has a large negative net foreign assets position. A country's international liabilities have to be serviced as long it maintains its obligations to its foreign lenders. Hence, other things held constant, a country with a large negative net foreign assets position is expected to have a deficit on its balance of income because its income payments to lenders should exceed its income receipts based on its earnings from assets abroad. However, the U.S. has had a favorable balance of income for many years in spite of running a current account deficit year in year out, a fact that H\&S exploit to expound their controversial thesis.

As a result of its persistent and large current account deficits, U.S.'s total international liabilities exceed its total international assets per official statistics. U.S.'s total international liabilities and total international assets can be valued in different ways. The two methods of valuing its international assets and international liabilities that are of relevance here are current cost basis and market value basis. Irrespective of how U.S.'s international liabilities and international assets are measured, its international liabilities exceed its international assets (see Charts 6 and 7). Foreign residents, including foreign governments, central banks, and foreign private residents, own more U.S. assets than the amount of foreign assets owned by U.S. residents and the U.S. government.

\section{$<$ INSERT CHART [6] HERE $>$}

\section{$<$ INSERT CHART [7] HERE $>$}

The U.S. net foreign asset, also known as its net international investment position, is negative and has been so since early 1990s. The country's net foreign assets position is a measure of the difference of its total international assets and its total international 
liabilities. The net foreign assets position can also be expressed in different ways, including current cost basis and market value basis.

Irrespective of how U.S. net foreign assets position is measured, it has deteriorated. The U.S. net foreign assets position, measured on a current cost basis, has deteriorated considerably since early 1990s (see Chart 8). As of 2005, the U.S. net international foreign assets position was nearly $-\$ 2.7$ trillion, which amounted to almost $22 \%$ of nominal GDP.

\section{$<$ INSERT CHART [8] HERE $>$}

U.S.'s net foreign assets position measured on a market value basis is also in the red, but it is worse when measured on a current cost basis. As of 2005, the U.S. net foreign assets position was about $-\$ 2.5$ trillion or just over $20 \%$ of nominal GDP (see Chart 9). On market value basis, the level of net foreign assets position appears to have remained fairly stable since 2002. Indeed, as a share of nominal GDP, the U.S. net foreign assets position has stopped deteriorating and in fact it improved by several percentage points since 2002.

\section{$<$ INSERT CHART [9] HERE $>$}

Favorable increases in the value of U.S. assets abroad and currency factors are responsible for the recent stabilization of net foreign assets position. Further, the rapid growth of U.S. nominal GDP are responsible for the improvement of this indicator as a share of nominal GDP. Nevertheless, even on a market value basis, the country's net foreign assets position has deteriorated noticeably since early 1990s.

The U.S. still maintains a net outflow of foreign direct investment despite the deterioration of the nation's net foreign assets position (see Chart 10). Indeed, the U.S. is a major source of global cross-border foreign direct investment.

\section{<INSERT CHART [10] HERE>}

U.S. multinational corporations continue to invest overseas aggressively. U.S. multinationals invest more overseas compared to how much foreign multinational corporations invest in the U.S. As a result, the stock of U.S. foreign direct investment abroad exceeds the stock of foreign direct investment in the U.S. (see Chart 11). The outward stock of U.S. foreign direct investment abroad, which amounts to just over $\$ 2.0$ trillion, is about one-third higher than the inward stock of foreign direct investment in the U.S., which amounts to less than $\$ 1.5$ trillion.

\section{<INSERT CHART [11] HERE>}

The U.S. earns more from its international assets than what it pays on its international liabilities. Another way of putting it is that the earnings of total U.S.- 
owned foreign assets exceed the earnings of total foreign-owned assets in the U.S. As a result, the U.S. income receipts on U.S.-owned assets exceed the income payments on foreign-owned assets in the U.S. (see Chart 12). In examining the international income receipts and international income payments data, it is useful to look at income receipts and income payments after respectively subtracting compensation to U.S. employees working abroad and foreign employees working in the U.S. After adjusting for these, the U.S. still has net income receipts but less so than otherwise.

\section{<INSERT CHART [12] HERE>}

"Dark Matter" Hypothesis. H\&S state that any asset that pays more must be worth more. If that claim is true then it would follow that since U.S.-owned foreign assets consistently pay more than foreign-owned U.S. assets they must be worth more. From these assumptions they then go on to revalue the U.S.'s net foreign assets position.

They reject various standard explanations. They dispute in particular the notion that the rate of return to U.S. investors is more than that to foreign investors. They reject the conventional wisdom which is at concordance with making appropriate adjustments in net foreign assets due to net capital gains.

They use an arbitrary price-earning ratio of 20 , or a rate of $5 \%$, in using income receipts to capitalize the income flow and for estimating the current account from the changes in the computed values of foreign assets for both the U.S. and for the rest of the world. They define current account deficit as the change in net foreign assets without any adjustments for net capital gains because they claim that such adjustments of net capital gains in net foreign assets are often ad hoc.

The gap between the cumulative current account deficit and the implied cumulative current account deficit based on H\&S's calculation is what they call "dark matter" (see Chart 13). They claim that the gap between these two measures reveal the "dark matter" that is missing in official international accounts. Based on their calculations they assert that the U.S.'s net foreign assets position has been virtually unchanged and that there is no current account deficit. The official view that the U.S. has a large and widening current account is spurious in their opinion.

\section{<INSERT CHART [13] HERE>}

Hausmann et al's conjecture is that since the U.S. earnings on its foreign assets is greater than the total foreign earnings from foreign-owned U.S. assets, the U.S. must be a net creditor rather than a net debtor. They believe that the U.S. international accounts do not properly measure intangible U.S. assets and other services that the U.S. provides. 
"Dark matter" originates from several sources, according to them. First, U.S. multinational corporations' foreign indirect investment embodies a variety of intangible capital, including proprietary intellectual capital, management acumen and business models, financial technology and financial engineering skills, brand names, and so forth. Each create value in ways that are not easy to measure and hence are not captured in official international accounts. Second, when the foreigners buy U.S.-issued Treasury securities in exchange of high-yielding but riskier assets, such as emerging market debts, the U.S. is implicitly selling insurance which is captured in the rate differential. This amounts to a sale of insurance services that is not measured in official statistics. Third, foreigners hold cash and other liquid U.S. dollar-denominated assets in lieu of less liquid but high-yielding foreign assets. These transactions amount to sales of U.S. liquidity services to foreigners that are not otherwise measured. Thus, the U.S. is a net provider of intangible capital, insurance services, and liquid capital. Of these intangible capital embodied in foreign direct investment is the most important.

The analysis of adjusting net foreign assets position based on the capitalization of net income receipts is extended to other countries. H\&S report that generally the world economy is much more balanced and is sounder than it is believed to be so in conventional analysis. The main exception is Japan, which turns out to be a formidable net creditor in their analysis. The European Union and the rest of the world have fairly small negative net foreign assets positions, none of which are worrisome.

They conclude by reiterating that the application of their methodology of capitalizing net income flows reveals that the U.S. has not run substantive current account deficits over the last two decades, the U.S.'s exports of "dark matter" appear to be solid and durable, and global imbalances are fairly minor and appear to quite stable.

Their findings, if correct, would lend credence to the view that the official current account deficits are fictitious, there is no need for any major adjustments or any major realignment of the exchange rate for U.S. dollar and that the risk of financial instability and turbulence due to current account adjustments is far-fetched and indeed quite erroneous.

We now assess the "dark matter" hypothesis critically.

\section{SECTION III: Critical Assessment}

The "dark matter" hypothesis is interesting and provocative. It appears plausible but several problems are evident with the hypothesis.

The official U.S. international accounts data based on detailed and careful surveys of U.S. assets abroad and foreign assets in the U.S. do not support it. The data on U.S.'s net 
foreign assets position show clearly that the U.S. has turned into a net debtor. While $H \& S$ doubt the veracity of the data on net foreign assets position and most current accounts items, they ironically assume that the data on income receipts and payments are correct and never raise doubts about its reliability. But the international income data can also be prone to errors, omissions, statistical discrepancies and so forth. Their case rely on the assumption that the data on international income payments and receipts are more reliable than the data on a country's international assets and liabilities.

Multinational corporations and international investors can and do shift funds from one line of current account to another. They do this within the parameters of tax rules and other regulatory restrictions in order to maximize their after tax returns. The tax authorities in advanced countries and key emerging markets require multinational firms to apply arms-length principle in valuing related party transactions. Nevertheless, multinational corporations use a variety of techniques within the permitted parameters of transfer pricing regulations to adjust their internal transfer prices to minimize their tax burden. The shifting of income from high tax jurisdictions to low tax jurisdictions could render international income payments and income receipts data as some misleading gauges for determining the values of a country's international assets and liabilities based on capitalization of income receipts and income payments respectively.

The profitability and the rates of return of U.S.-owned assets abroad and foreignowned assets in the U.S. can and do vary. The ratios of asset values and the income generated by the U.S.-owned foreign assets and foreign-owned U.S. assets can differ due to uncertainty, different macroeconomic circumstances, institutional rigidities and specificities, and home bias in investors' portfolio allocation. The preferences and the attitudes toward risks of U.S. investors holding foreign assets and that of foreign investors holding U.S. assets may also differ.

U.S. investors and foreign investors may hold different types of assets, resulting in variation in earnings from such assets. It will be shown that there is a substantive difference in the types of assets that U.S. investors and foreign investors hold.

The willingness of foreigners to accept lower returns (at least to date) could be due to the fact that they view U.S. investments as a very safe asset, almost like a certificate of deposit. Economies coming into money for the first time (for example, China) have a desire to build up a cash cushion.

The experience of currency crisis in Asia in the late 1990s may have caused many foreign governments and private investors to be wary of currency fluctuations, asset price volatility and sudden stops in capital flows. For such precautionary purposes, yield is not that important, but the safety and the security of the asset is a much more important concern. As a result, official and private investors from some countries, like China, tend to purchase safe assets, such as U.S. Treasury securities and government 
sponsored enterprise securities, because they view the U.S as a safe haven and dollardenominated U.S. assets as safe haven assets.

Once a precautionary cushion has been created, foreigners may be more concerned about higher yield and securing higher total returns. It is certainly possible that foreign governments, foreign central banks, and to a lesser extent foreign private investors are approaching that critical threshold, if they are not already at this point. Asian countries have been building considerable foreign exchange reserves, most of which consists of U.S. dollar reserves. Over time, however, they are likely to diversify their portfolio.

Composition Differences. A key reason why the earnings from U.S. assets abroad are much higher than foreigners' earnings from their assets is the difference in the types of assets they respectively hold. The composition of U.S.-owned foreign assets differs substantially from the composition of foreign-owned U.S. assets (see Charts 14 and 15).

\section{<INSERT CHART [14] HERE>}

\section{<INSERT CHART [15] HERE>}

Among U.S.-owned foreign assets, foreign direct investment is quite important. Its share in total U.S.-owned foreign assets has been fairly stable, around $25 \%$ to $30 \%$. However, the share of foreign securities has increased noticeably over the years, rising to nearly $40 \%$. The share of U.S. official assets and other types of assets in total U.S.owned foreign assets is quite small.

Foreign-owned U.S. assets differ quite a bit from U.S.-owned foreign assets. Securities other than U.S. Treasury constitute the biggest chunk of foreign-owned U.S.assets, followed by U.S. bank liabilities. The share of securities other than U.S. Treasury securities has increased over time, as has the share of foreign official assets. Foreign direct investment in the U.S. constitutes merely $15 \%$ of foreign-owned U.S. assets as of 2005, and its share has declined from around 21\% in 1991.

The contrast between U.S.-owned assets and foreign-owned U.S. assets becomes starker when one examines the different types of securities that U.S. residents own abroad and those that foreigners own in the U.S. (see Charts 16 and 17). The bulk of U.S.-owned foreign securities is in stocks, while the remainder is in different types of bonds. The share of stocks have trended to increase over time, constituting nearly $76 \%$ in 2005 up from less than $60 \%$ in 1990 . But the share of bonds has declined, constituting about $24 \%$ in 2004 down from over $40 \%$ in 1990. The bulk of foreign-owned U.S. assets is held in the forms of U.S. Treasury securities and bonds. As of 2005, the share of U.S. Treasury securities and bonds constituted respectively $14 \%$ and $42 \%$ of total foreign assets in the U.S., with stocks being merely $44 \%$.

<INSERT CHART [16] HERE> 


\section{<INSERT CHART [17] HERE $>$}

While the there have been some changes in the shares of U.S. Treasury securities, bonds, and stocks among foreign-owned securities since the mid-1990s, foreigners' portfolio of U.S. securities are much more conservative than U.S. residents' portfolio of foreign securities. Likewise, the above analysis of total foreign-owned U.S. assets shows that it is much more conservative than total U.S.-owned foreign assets.

Given the compositional difference between total U.S.-owned foreign assets and total foreign-owned U.S. assets, as well as the compositional difference between U.S.-owned foreign securities and foreign-owned U.S. securities, it is entirely plausible for U.S.owned foreign assets to generate more income than foreign-owned U.S. assets. The mean rate of return from U.S.-owned foreign assets could well be sufficiently larger than the mean rate of return from foreign-owned U.S. assets. Thus, even though the value of total U.S.-owned foreign assets is less than the value of total foreign-owned U.S. assets, they generate a higher income than foreign-owned U.S. assets. As a result, the U.S. continues to obtain net income receipts despite its deteriorating current account deficit and its negative net foreign assets position.

Different classes of assets can and do generate earnings and returns that vary. But H\&S do not acknowledge that the substantive compositional differences between U.S.owned foreign assets and foreign-owned U.S. assets can effect their potential and actual earnings.

Other issues. Besides the compositional differences, other issues also impair H\&S audacious hypothesis.

$H \& S^{\prime} s$ use of invariant and same price-to-earnings ratios to estimate net foreign assets position for both U.S.-owned foreign assets and foreign-owned U.S. assets based on capitalizing net income receipts is unjustified. The price-to-earnings ratios vary considerably for most markets overtime and also vary among different markets. Both asset prices and earnings are volatile series. Hence, the price-earnings ratios are more likely than not to be itself a volatile series.

The S\&P 500 price-to-earnings ratio, which is a fairly broad and representative measure of the price-earning ratio for corporate America, has varied considerably over time (see Chart 18). The price-earnings ratio fluctuates due to evolving macroeconomic and business cycle conditions. It may be influenced by changes in corporate profits, dividend policy, corporate governance, stock buybacks, waves of corporate mergers and acquisitions, and regulatory regimes. It may even spike up and down due to vagaries of the financial markets, including speculative bubbles and rational herding in financial markets. 


\section{<INSERT CHART [18] HERE $>$}

Overseas markets tend to offer opportunities for cheaper and higher growth and increasing total returns, besides diversification. That is why U.S. multinational corporations and U.S. residents invest overseas in quest for growth and higher profitability. The investment bank UBS, a leading Swiss financial firm, estimates that in 2006 price-earnings ratios will be lower in most developed world, including the euro zone and Japan, compared to the U.S. (see Chart 19). Emerging markets will also have lower price-earnings ratios. Other data corroborate this view. Analysis of iShares MSCI index fund price earnings ratio shows that, with a few exceptions aside, such as U.K., Italy, Sweden, and Malaysia, the U.S. has a higher price-earnings ratio than that of most other countries and regions of the world (see Chart 20).

\section{<INSERT CHART [19] HERE>}

\section{<INSERT CHART [20] HERE>}

Lower price-earning ratios overseas compared to those of the U.S. imply that the rates of return are higher overseas than in the U.S. Hence, the assumption that that price-earnings ratio is stable over time and similar across different markets is unwarranted and rather misleading. H\&S make a simple but fundamental error in making such a naïve assumption.

There may also be structural reasons for earnings of U.S.-owned foreign assets to be higher in the rest of the world than that generated by foreign-owned assets in the U.S. Most of U.S.-owned assets, particularly the outward stock of its foreign direct investment, are located in Western Europe and Japan. But the level of product market competition in Europe and Japan are much less than in the U.S. due to higher entry barrier and barriers to competition, barriers to trade and investment, and higher degree of state control in the economy (see Chart 21). The lack of product market competition, however, can increase the profits margin and the rates of return for incumbent firms, including U.S. multinational corporations that are already established abroad. More product market competition in the U.S. exerts pressure to lower profits margins and the rates of return. This could be a reason for comparatively higher earnings on U.S.-owned foreign assets, particularly its outward foreign direct investment, than foreign-owned U.S. assets, particularly foreigners' inward direct investment in the U.S.

\section{<INSERT CHART [21] HERE>}

In sum, the higher earnings on U.S. investment abroad compared to the earnings on foreign investment in the U.S. do not necessarily imply that the U.S. is a net creditor, contrary to H\&S's conjecture. There are plausible explanations for the stylized facts. Foreigners have a certain preference for U.S. assets, dollar-denominated securities and for investing in the U.S. They are willing, thus, to accept a lower return on assets in the U.S. compared to the returns that U.S. residents are willing to accept for U.S.-owned 
foreign assets. The compositional difference in the types of assets that foreigners hold in the U.S. and those that U.S. residents hold abroad may lead to differences in the priceearnings ratios of U.S.-owned foreign assets abroad and foreign-owned U.S. assets. There are vast differences in economic, financial, and political risks between the U.S., and the rest of the world. The returns of foreign-owned U.S. assets may be less than that of U.S.-owned assets in smaller open economies due to a premium that U.S. investors require to put their funds in small open economies.

\section{SECTION IV: Conclusions}

The benign neglect of the long-term sustainability of U.S. current account deficit on the grounds of the alleged existence of unobserved intangible capital, based on some disputable estimates of the amount of U.S.-owned intangible capital abroad, would be an unwise stance for policymakers. The widening current account deficit should remain a matter of concern because it leads to increased indebtedness to foreigners and requires a country to devote more of its productive resources to service its debt and meet its external obligations.

The strong growth, impressive gains in labor productivity and total factor productivity, flexibility and dynamism, openness to trade, immigration and financial flows, technological progress, entrepreneurial culture, the ease of doing business, and the institutional robustness have contributed to the resilience of the U.S. economy. The role of the U.S. as the world's leading economic and military power in the world gives the U.S. a unique role in the international financial system. International investors continue to invest in the U.S. because they are confident that the U.S. can meet its future net foreign liabilities' service obligations. They believe that the U.S. economy will grow at a healthy pace, its institutions will remain stable, and the country will continue to flourish.

If, however, the current account continues to stay at its current level or rises as a share of nominal GDP in the coming years, then the U.S. will certainly have to recourse to some sort of adjustment in order to stabilize or reverse its current account deficit. Such adjustments will require some combination of curtailment of domestic demand and consumption, expenditure switching, reduction of fiscal deficit, and increase in the competitiveness of U.S. goods and services.

Increased competitiveness of U.S. exports would come about through conspicuous depreciation of the real effective exchange rate. It would make U.S. goods and services cheaper in terms of foreign currencies to the rest of the world. Most analysts expect a gradual adjustment process in the years ahead with some depreciation of the real trade 
weighted U.S. dollar. There is, however, a downside risk of abrupt adjustment of the exchange rate and a contraction of domestic demand and overseas production. This would impose substantial costs on the U.S. and the global economy, particularly major exporting countries that rely on the U.S. as the final market for goods and services produced in those economies.

The criticisms presented here raise doubts about the validity of the "dark matter" hypothesis. H\&S's claims of the existence of vast amounts of U.S. capital intangible overseas should be disputed. Unless such claims can be theoretically substantiated and empirically verified, conjectures about the large presence of U.S.-owned intangible capital abroad cannot be accepted prima facie. Moreover H\&S's arguments appear to be contingent on crucial assumptions and a methodology that may not be justified.

Therefore, one should remain skeptical of their claims.

Intangible capital, however, is and will be a crucial component of net foreign assets going forward in advanced, knowledge-based and service-oriented economies. Intangible capital may play increasingly important role in tomorrow's economies around the world. Going forward, proper measurements of intangible capital and reliable data on cross-border financial and capital flows that duly includes intangible capital will be critical to understanding international financial relations in global macroeconomics.

Resolving global imbalances is the joint responsibility of the international community. U.S. and overseas authorities and multilateral institutions, such as the IMF, should support policies to increase public and private sectors' saving in the U.S., stimulate structural reforms in Europe and Japan to raise growth, facilitate more efficient financial intermediation and greater exchange rate flexibility in Asia, and liberalize global trade rules to enable adjustment of global imbalances in an orderly manner. ${ }^{3}$

\footnotetext{
${ }^{3}$ See Khan (2004 and 2006) for a detailed discussion in the context of a new global financial architecture.
} 


\section{References}

Hausmann, Ricardo, and Federico Sturzenegger, “U.S. and Global Imbalances: Can Dark Matter Prevent a Big Bang?" (November 2005).

<http://www.cid.harvard.edu/cidpublications/darkmatter_051130.pdf>

Hausmann, Ricardo, and Federico Sturzenegger, "Global Imbalances or Bad Accounting? The Missing Dark Matter in the Wealth of Nations," CID Working Paper No. 124. Center for International Development at Harvard University (May 2006).

$<$ http://ksghome.harvard.edu/ rhausma/publication.htm\#wp>

Khan, Haider A., "Managing Global Risks and Reforming the IMF: Towards a New Global Financial Architecture," in J. Nakagawa ed. Managing Global Transitions, London: Routledge, 2006.

Khan, Haider A., "Global Markets and Financial Crises," in Asia: Towards a Theory for the 21st Century, Basingstoke, U.K.: Palgrave/Macmillan, 2004.

Zandi, Mark, "Red Ink," Regional Financial Review (March 2005). 


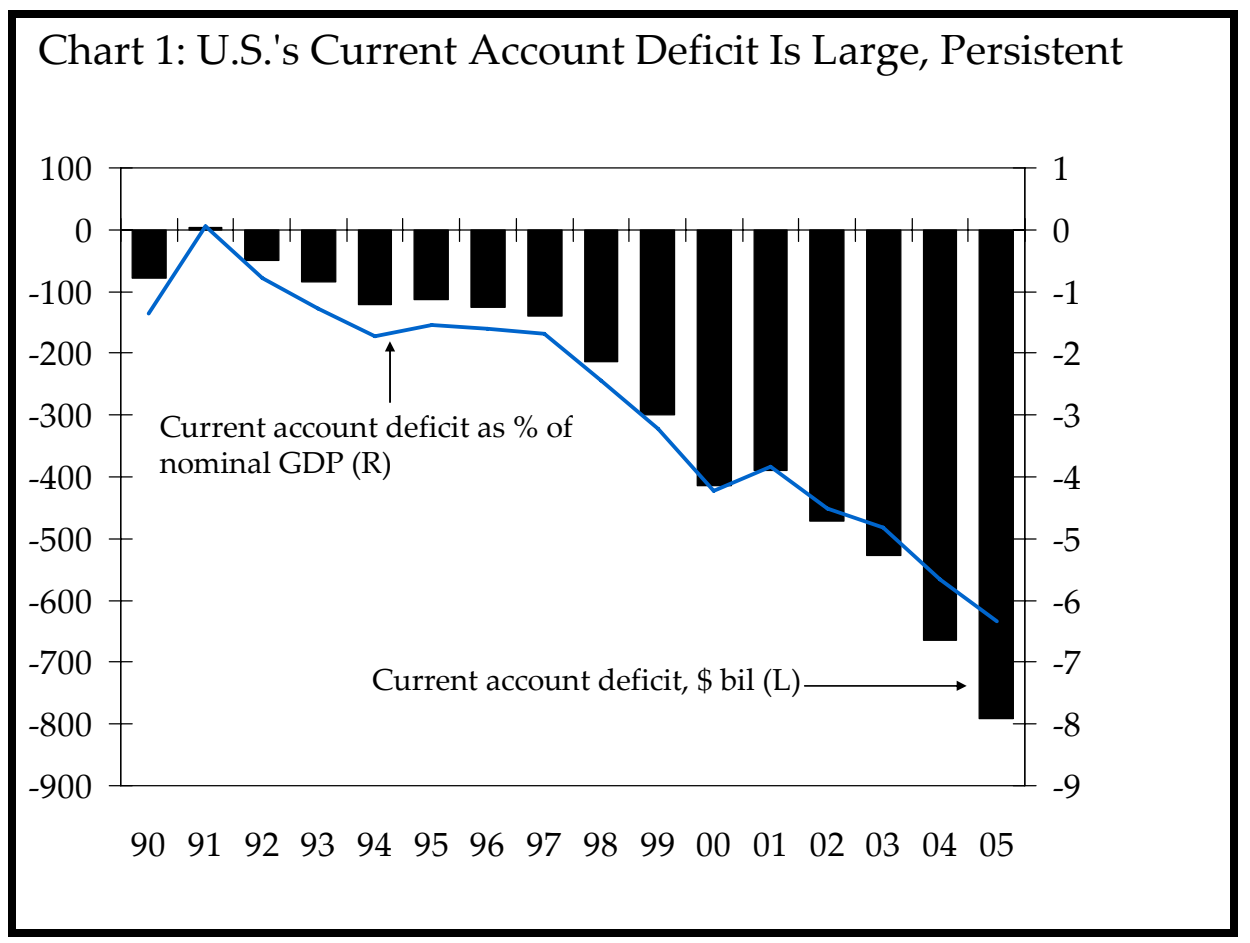

Chart 2: U.S. Is the World's Largest Importer of Capital

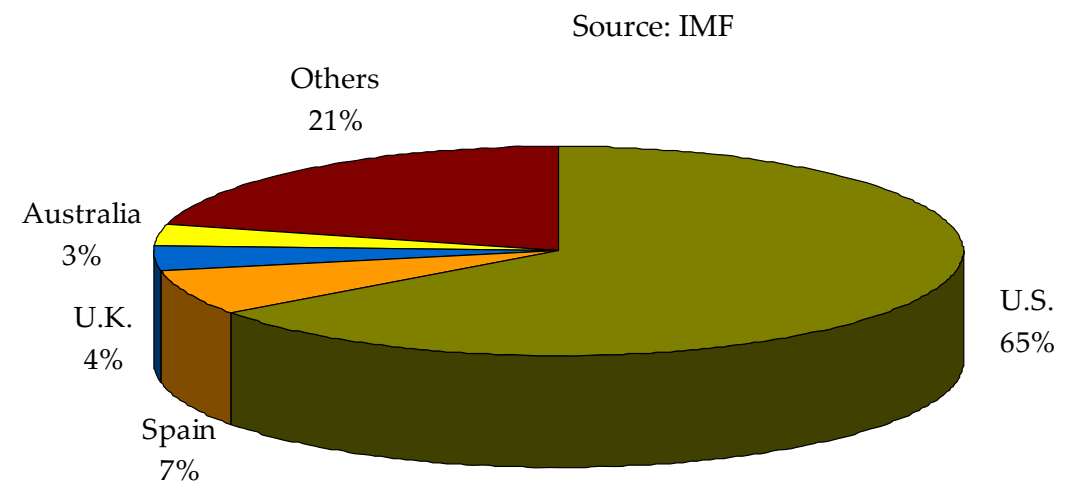


Chart 3: Asian Countries Are the Major Exporters of Capital

Source: IMF

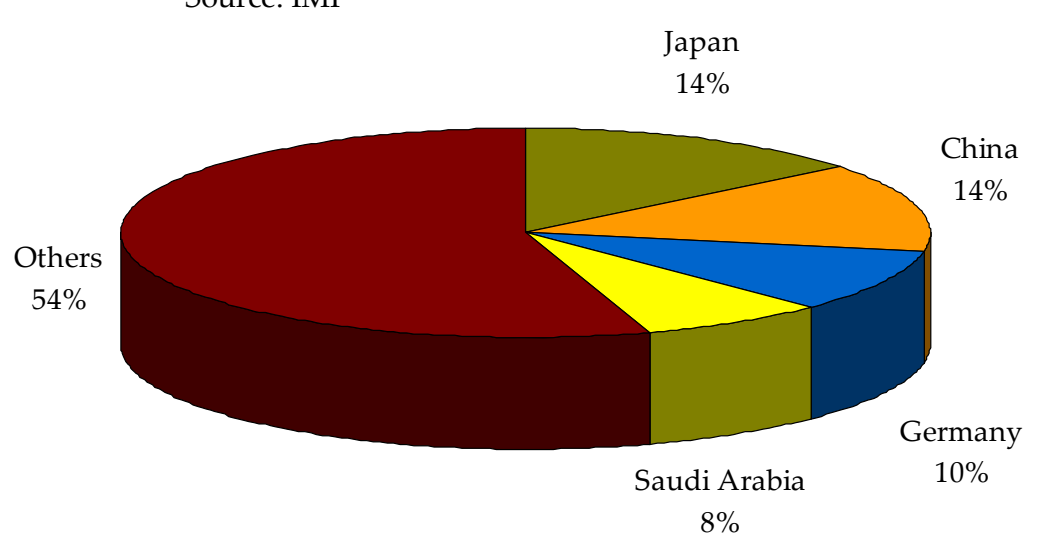

Chart 4: Trade Deficit Drives U.S. Current Account Deficit $\$$ bil

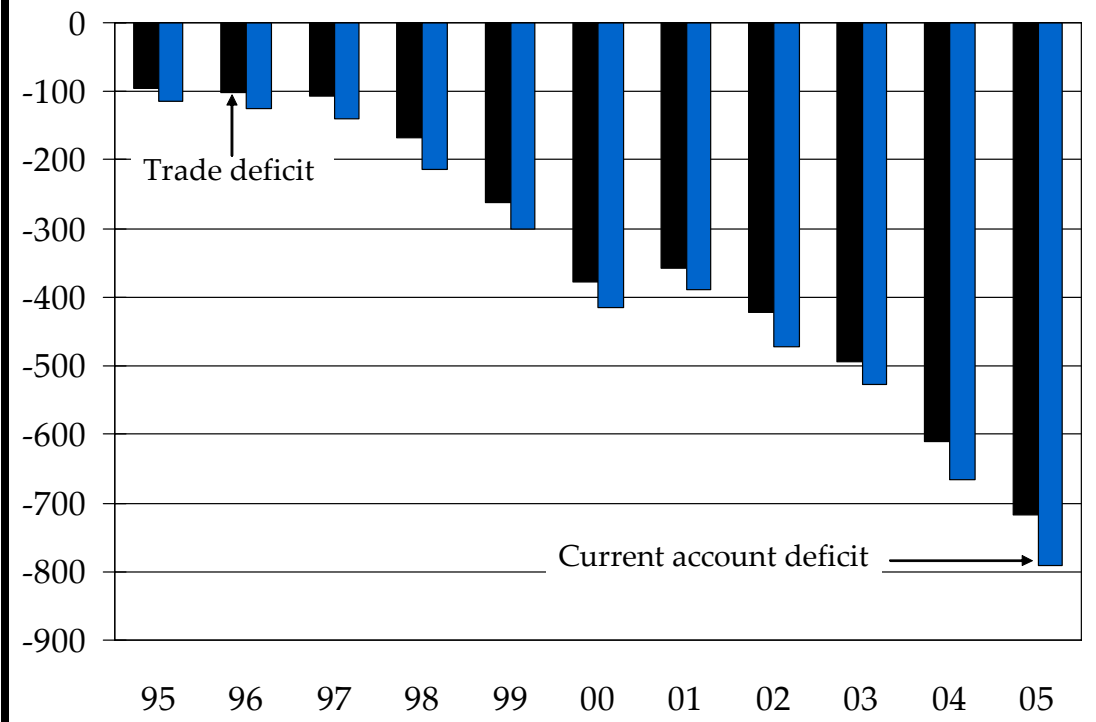




\section{Chart 5: U.S. Still Has a Positive Net Income on Investments}

Components of U.S. current account, \$ bil

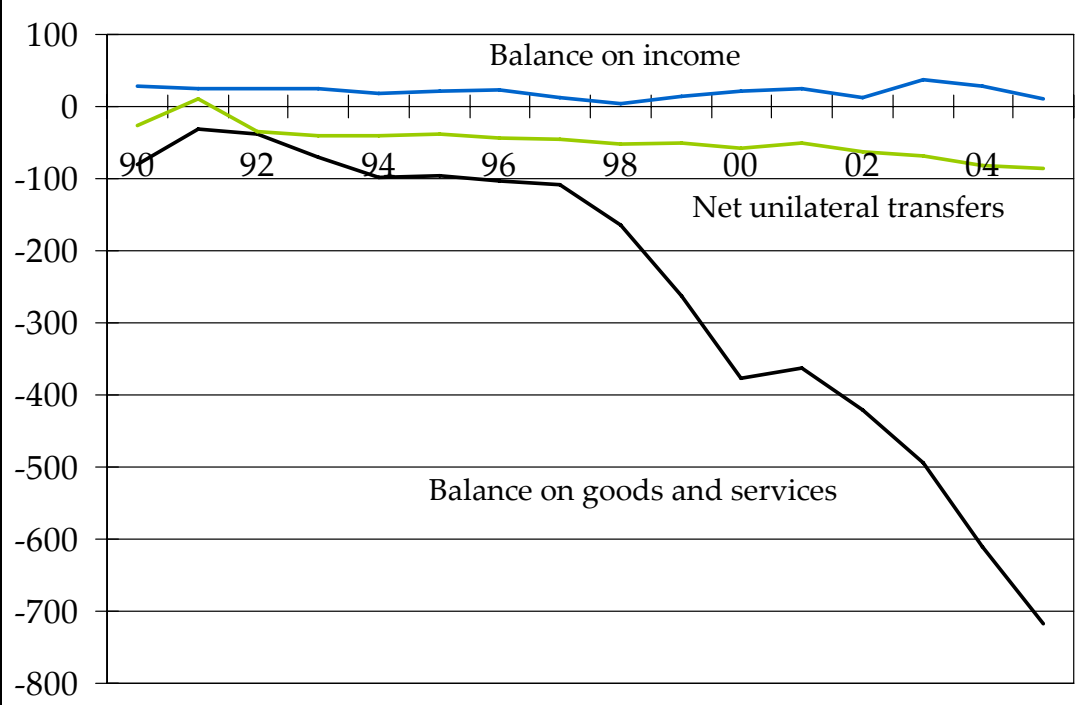

Chart 6: U.S. International Liabilities Exceeds Assets

Current cost basis, \$ tril

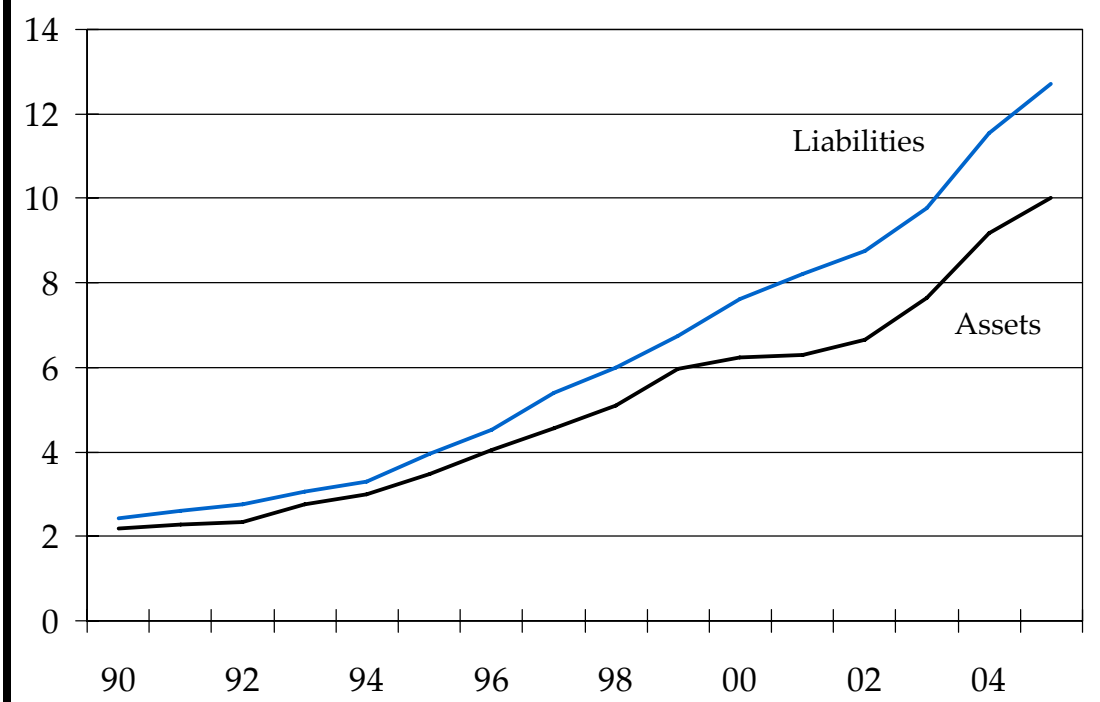


Chart 7: U.S. International Liabilities Exceeds Assets

Market value basis, \$ tril
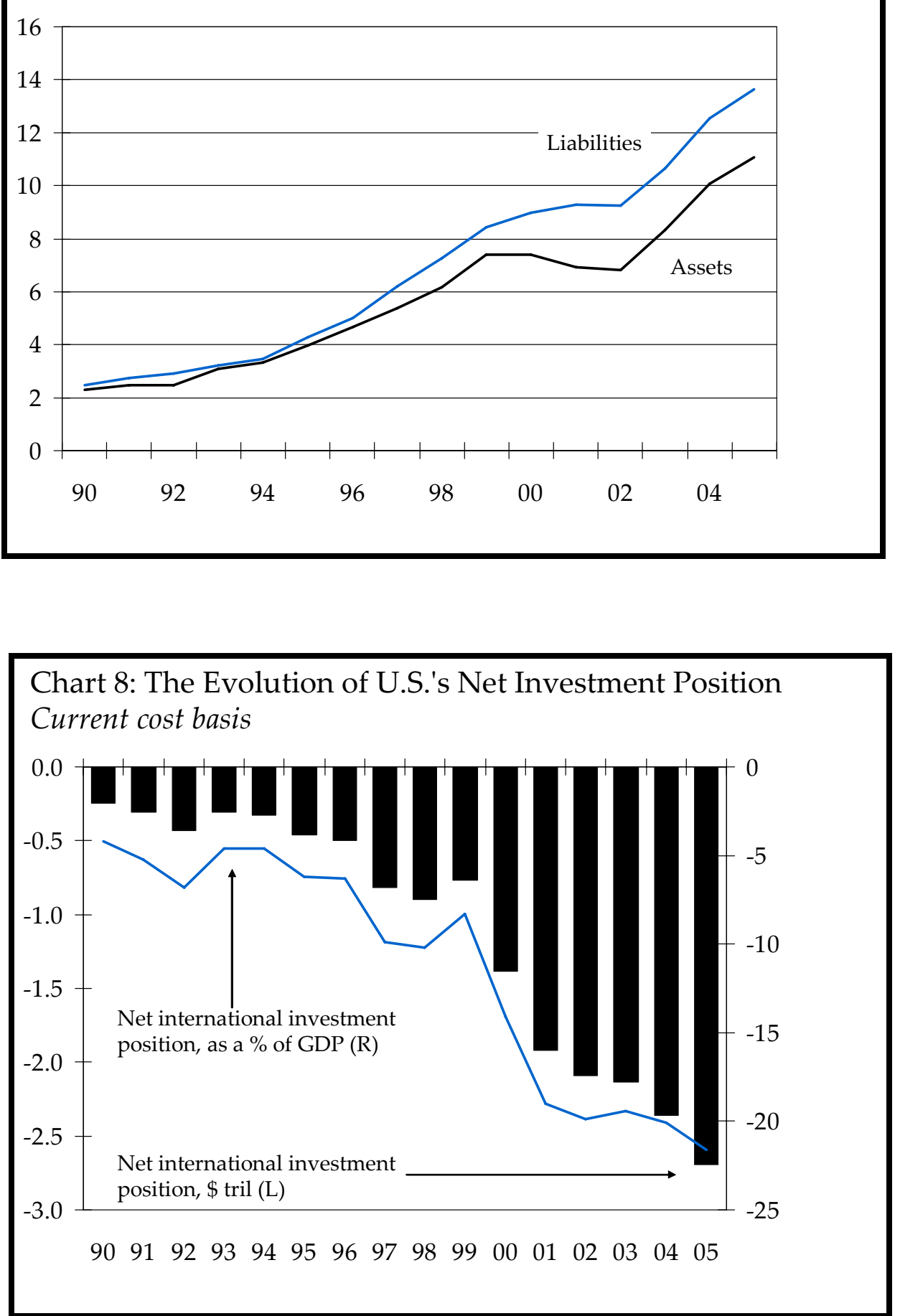
Chart 9: The Evolution of U.S.'s Net Investment Position Market value basis

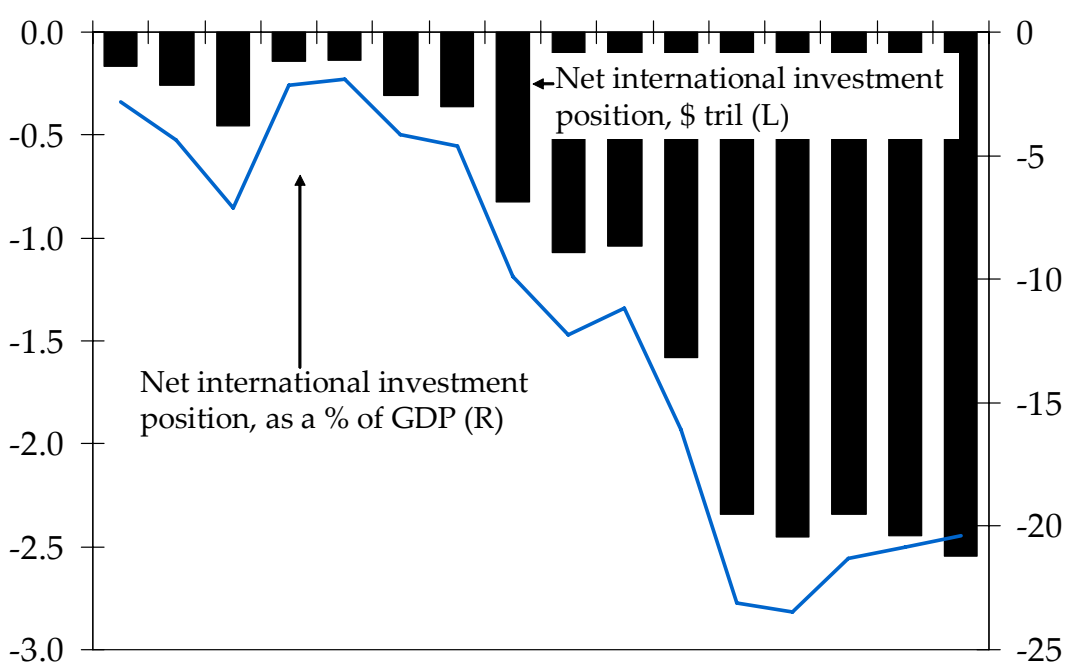

$\begin{array}{llllllllllllllll}90 & 91 & 92 & 93 & 94 & 95 & 96 & 97 & 98 & 99 & 00 & 01 & 02 & 03 & 04 & 05\end{array}$

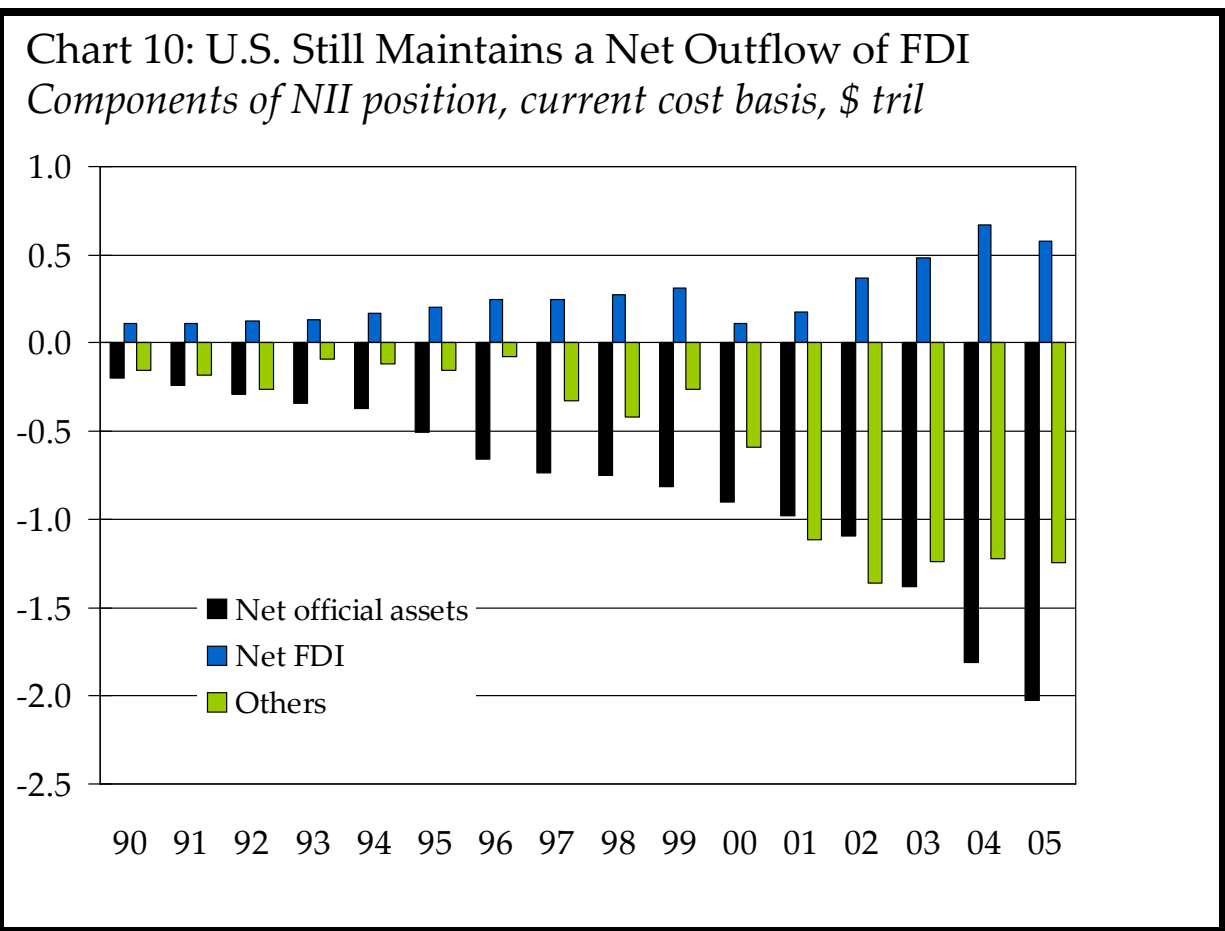


Chart 11: U.S. Outward FDI Stock Exceed its Inward Stock FDI stock, \$ tril, 2004

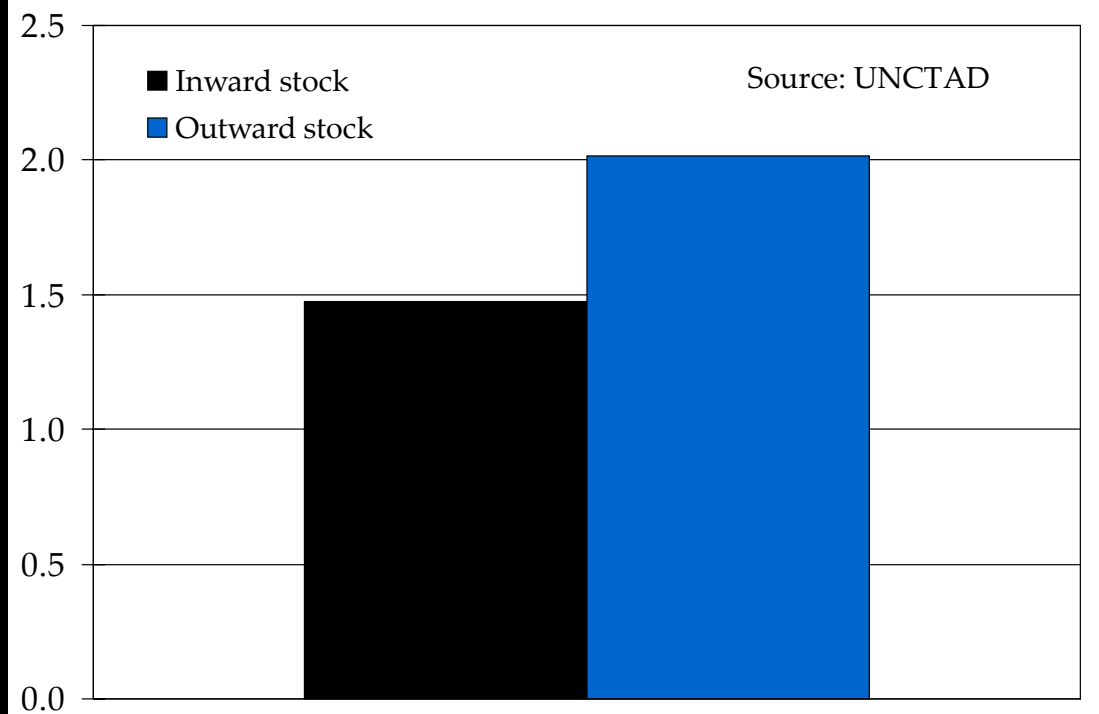

Chart 12: U.S. International Income Payments \& Receipts $\$$ bil

500

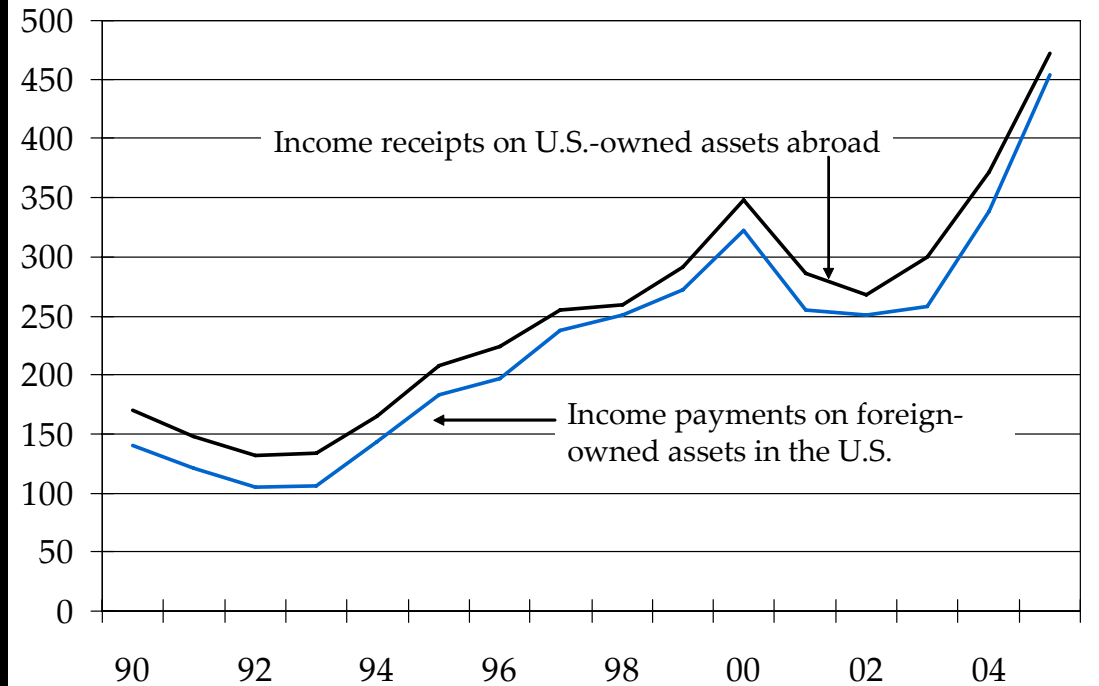




\section{Chart 13: Cumulative Current Account}

\$ tril

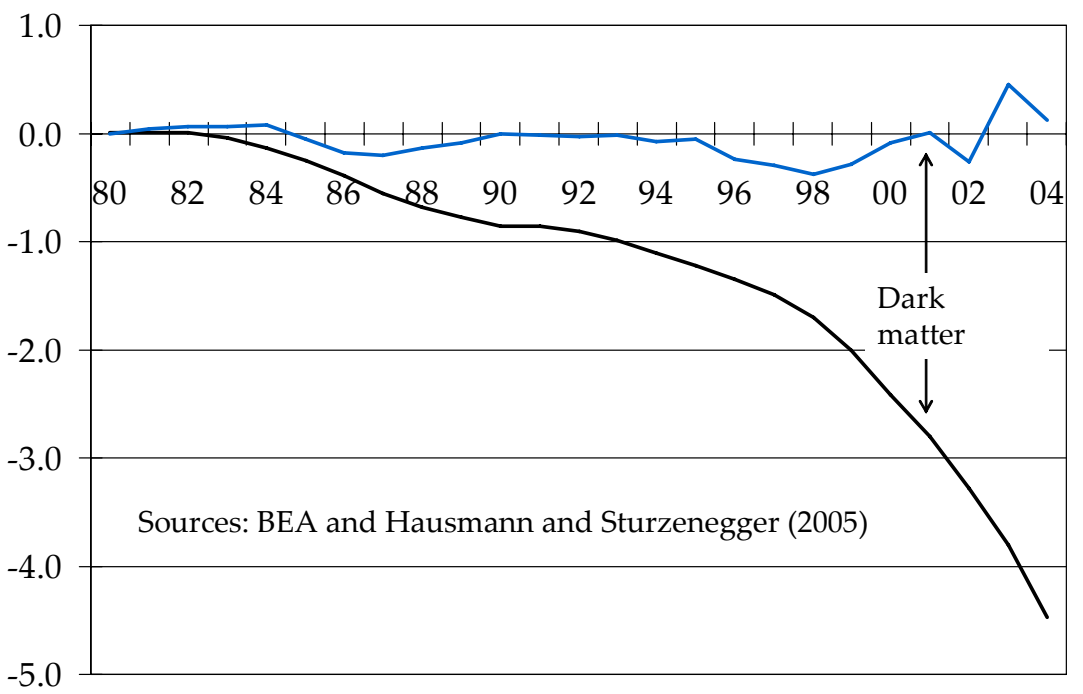

Chart 14: Composition of U.S.-Owned Foreign Assets

$\%$ of total U.S.-owned foreign assets

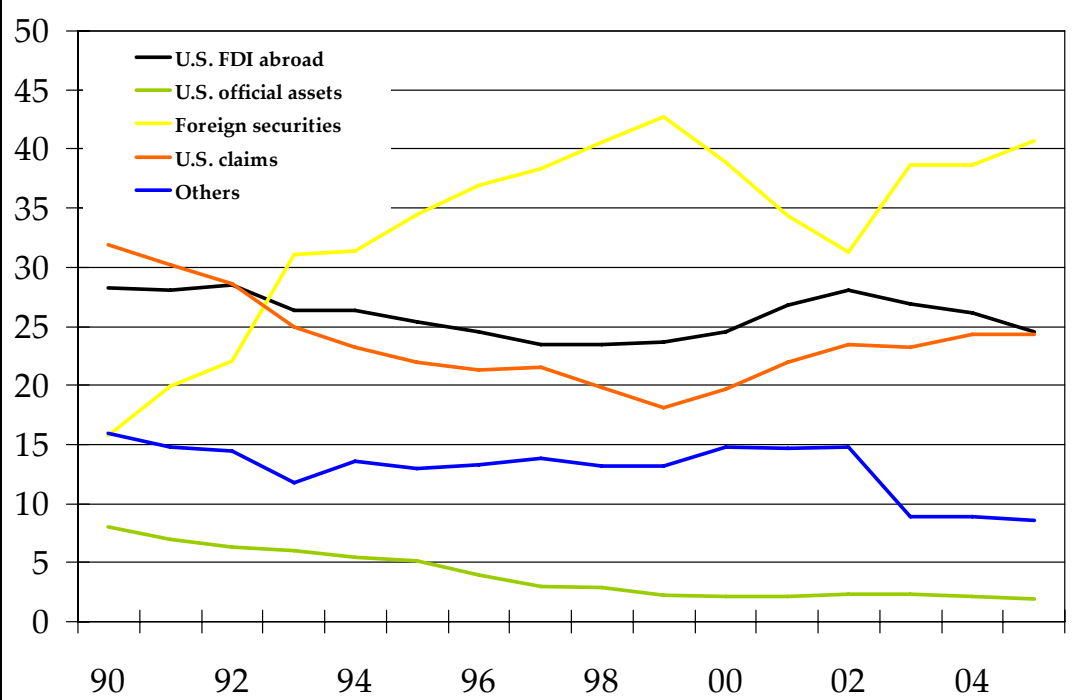


Chart 15: Composition of Foreign-Owned U.S. Assets

$\%$ of total foreign-owned U.S. assets

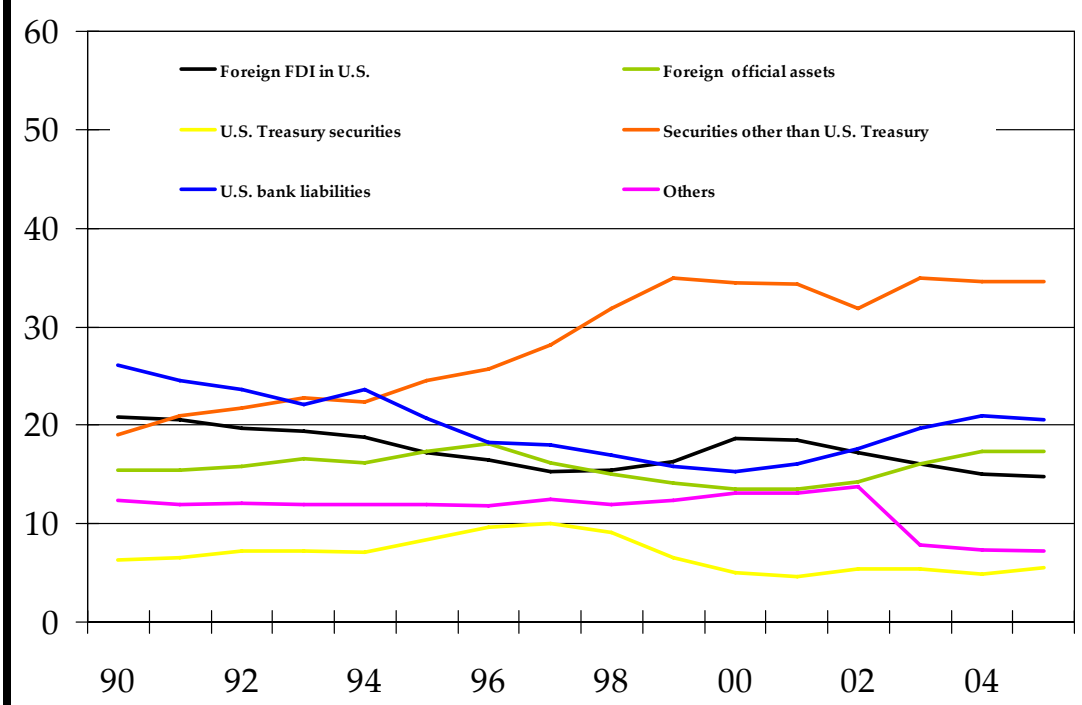

Chart 16: Composition of U.S.-Owned Foreign Securities $\%$ of total U.S.-owned foreign securities

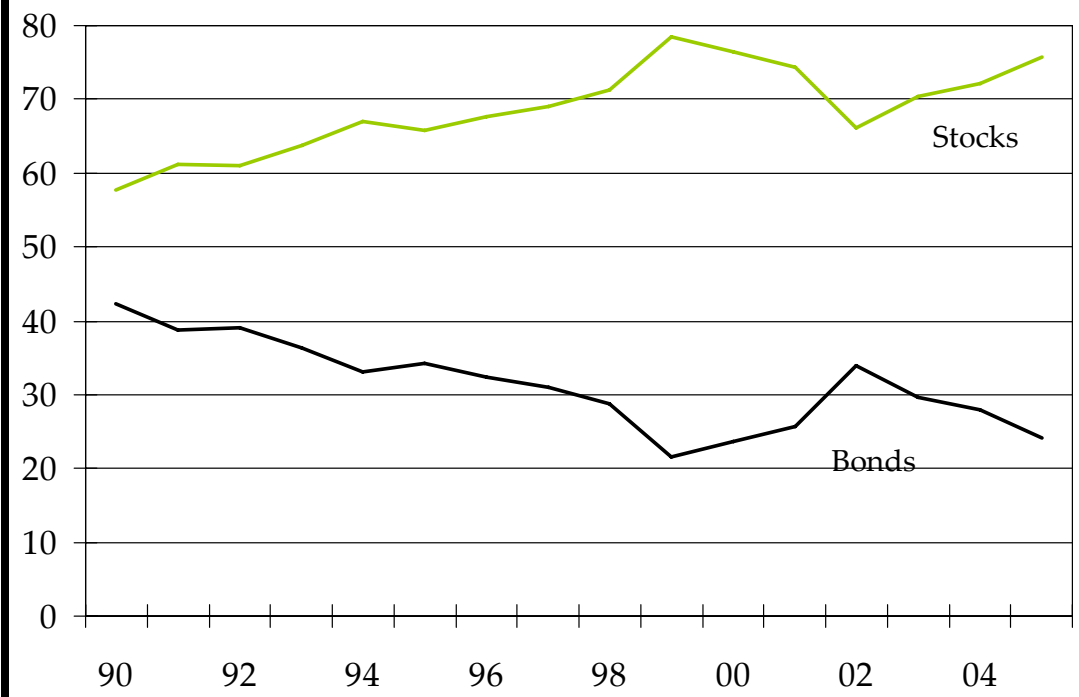


Chart 17: Composition of Foreign.-Owned Securities

$\%$ of total foreign-owned U.S. securities

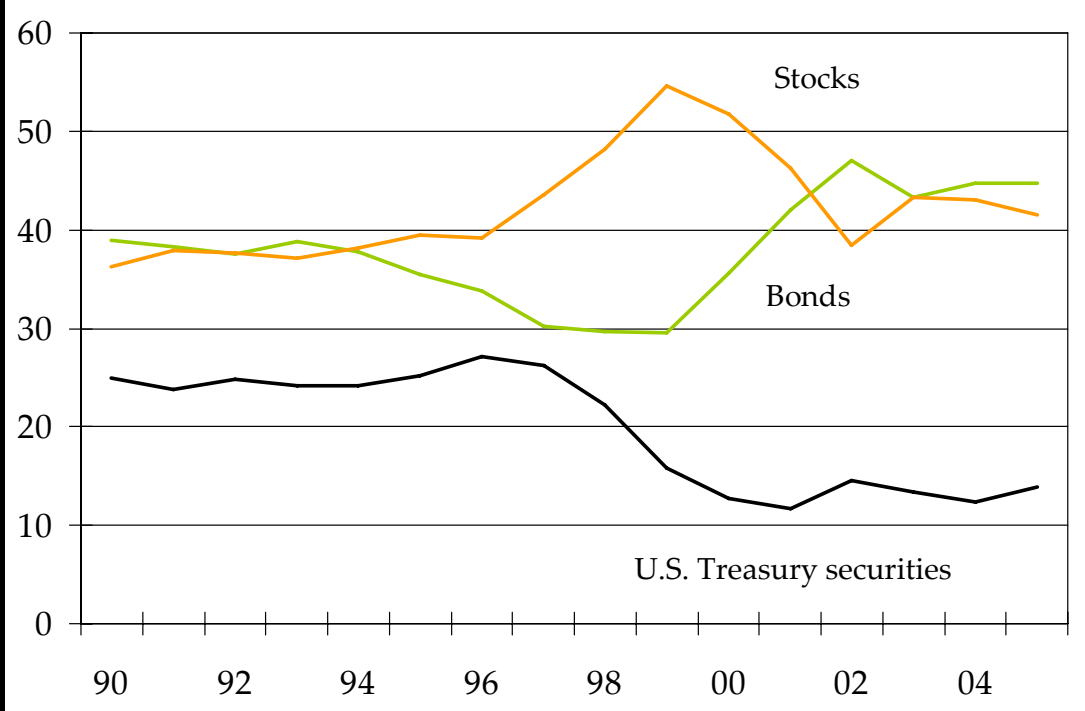

Chart 18: The Evolution of S\&P500 P/E Ratio

Pricelearnings ratio, \%, NSA, monthly average

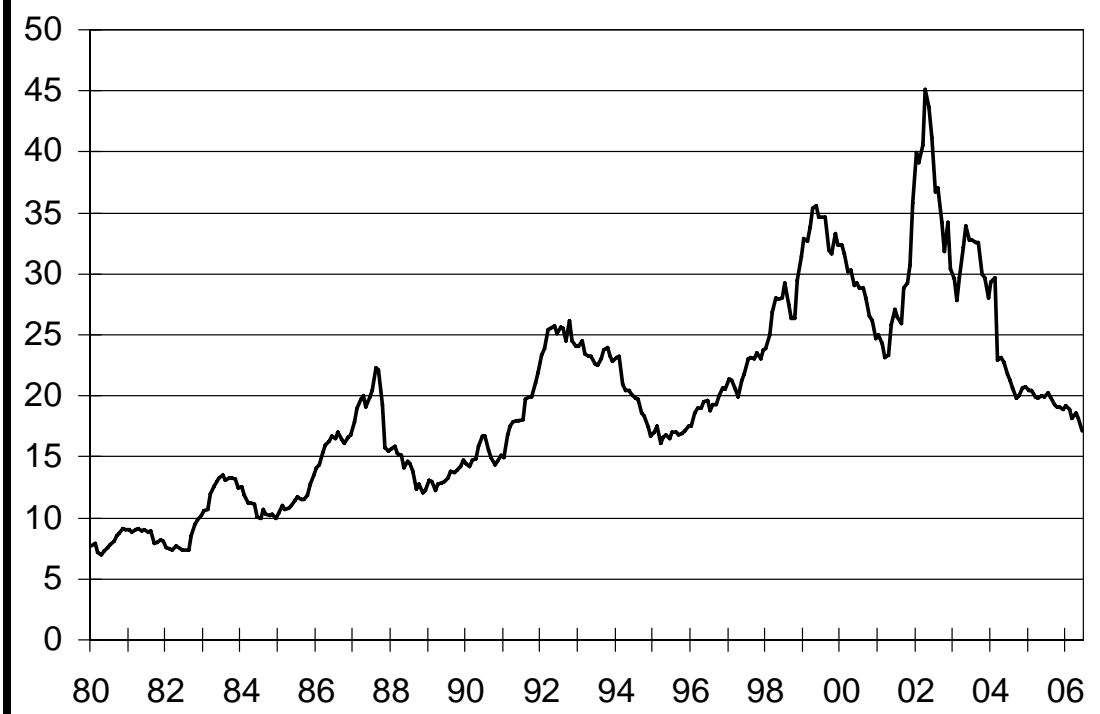


Chart 19: Foreign Markets Offer Cheaper \& Higher Growth Pricelearnings ratio, $2006 \mathrm{~F}$

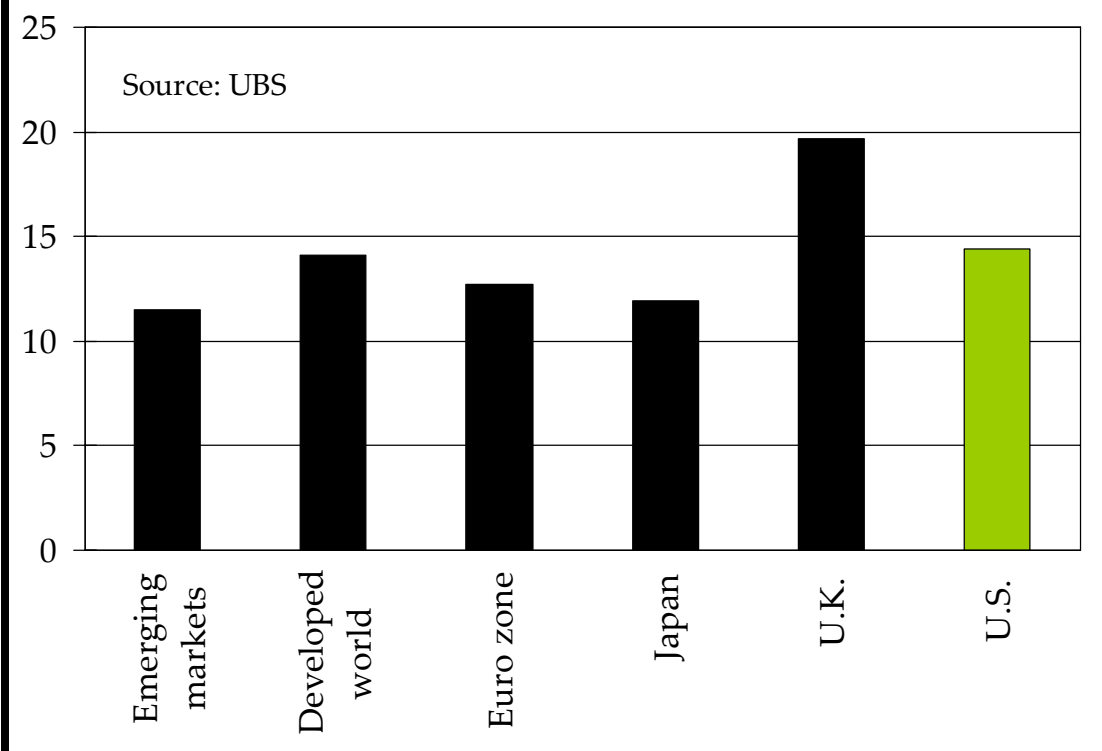

Chart 20: Lower P/E Ratios in Most Countries and Regions iShares MSCI index fund P/E ratios, June 28, 2006

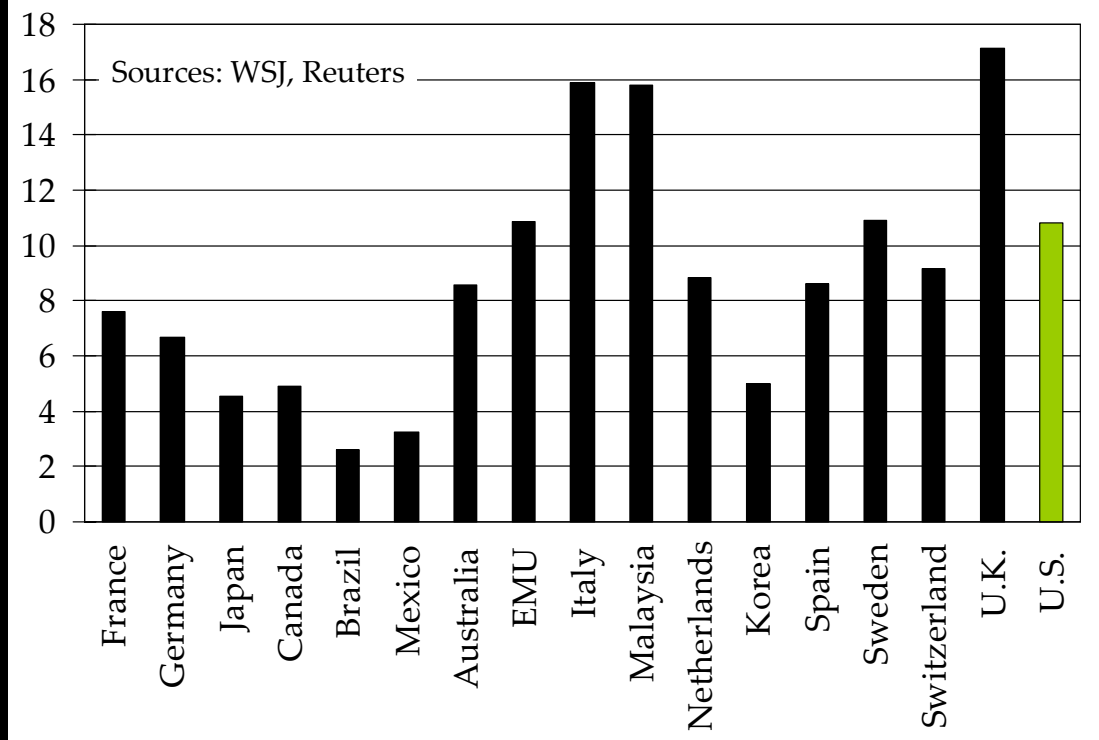


Chart 21: More Product Market Regulation Abroad

Overall product market regulation indicator, 2003

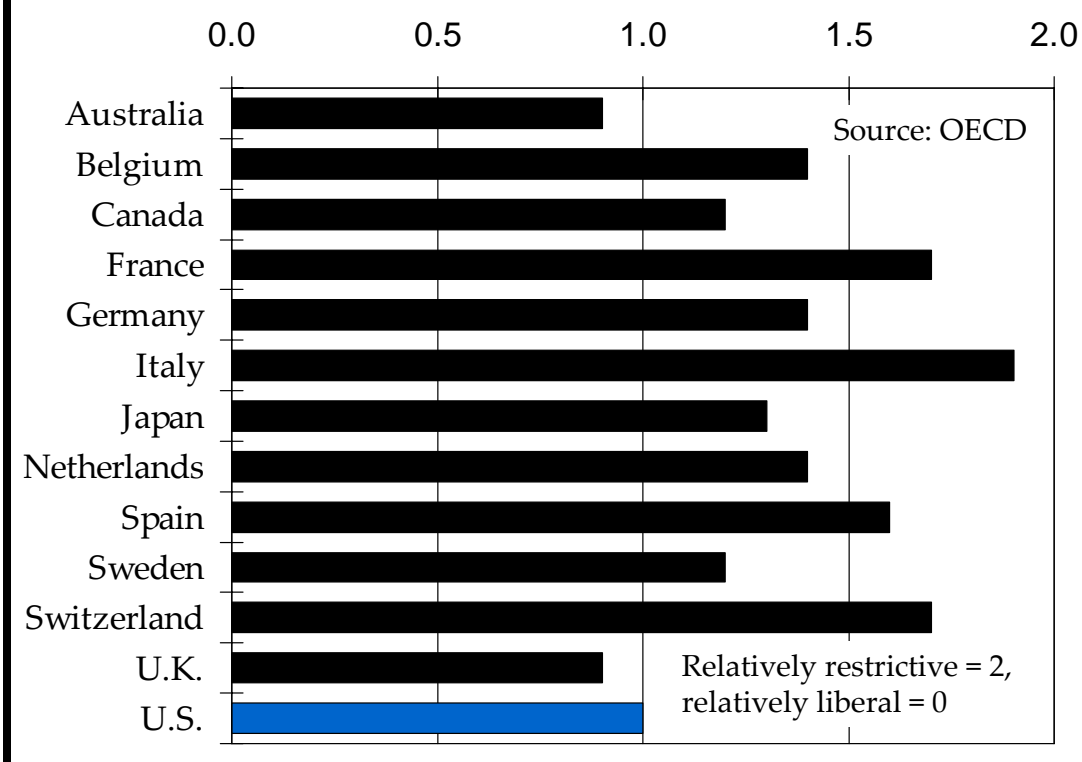

